\title{
Efficiency of Effective Microorganisms (EM) to Induce Resistance against Chocolate Spot Disease and Enhance Productivity of Faba Bean under Reclaimed Soil Conditions Abeer M.A. El-Hadidy* and A.A. Abd El-Ati**
}

* Plant Protect. Dept., Desert Res. Centre, El-Mataria, Cairo, Egypt.

** Plant Production Dept. Desert Res. Centre, El-Mataria, Cairo, Egypt.

\begin{abstract}
Qeries of experiments including in vivo, greenhouse and field trials were conducted at Noubariya district, Behera Governorate, Egypt during two successive winter seasons (2009/10 and 2010/11) to investigate the effect of foliar application with some biotic formulas based on effective microorganisms (EM) as resistance inducers for faba bean (Vicia faba L.) growth, total pigments and chlorophyll, yield as well as chocolate spot disease resistance cause by Botrytis fabae. Onion, garlic or cabbage were used to formulate these biotic formulas in EM1 or EM5. Application of these biotic formulas at the concentrations of $4 \%$ and $8 \%$ significantly suppressed the disease severity and increased total pigments, chlorophyll and phenols contents, enzymes activity and, therefore, plant growth and productivity. Results indicated that when the infection of chocolate spot disease, caused by Botrytis fabae, exists as a serious common biotic stress, the usage of the biotic formulas as inducers is essential as clean development mechanism (CDM) concept to satisfy the needs of the clean agriculture. When the infection alert is existing at the vegetative stage; the foliar application either with (EM5+garlic) $4 \%$, (EM5+onion) $8 \%$ or (EM5+onion 4\%), respectively, once at 30 days after sowing date is highly recommended. In case of the alert is postponed until the flowering or reproductive stage, foliar application with (EM5+garlic) $8 \%$ once at 60 days after sowing date is precisely a must.
\end{abstract}

Keywords: Botrytis fabae, cabbage, CDM, chocolate spot disease, EM, faba bean, garlic, induced resistance and onion.

Egypt ranked the first among the faba bean importing countries with $0.23-0.3$ mega tons at the last five years (Anonymous, 2011). This is a result for the huge consumption, limited area for growing and its high acceptability for many foliar diseases particularly in the new reclaimed areas such as Noubariya district, Behera Governorate (Abou-Zeid and Hassanein, 2000).

Chocolate spot disease caused by Botrytis fabae is one of the serious biotic stresses. It economically damages the foliage, limits photosynthesis activity, and reduces faba bean production either globally (Torres et al., 2004) or in North Egypt (Abou-Zeid and Hassanein, 2000). In Nile Valley, such as North Ethiopia, yield losses due to chocolate spot disease reached $60-80 \%$ among sensitive cultivars, 
while up to $34 \%$ among tolerant cultivars (Sahile et al., 2008). This disease can also cause total crop failure under severe epidemic conditions (Torres et al., 2004). As an obligation, controlling this disease is one of the important solutions to bridge the faba bean production deficiency.

Despite of the global consensus on controlling plant diseases is essential for food security, yet pesticides application is one of the most serious environmental pollutants. It causes severe problems such as carcinogenicity (Epstein et al., 1967), long persistence period (Beye, 1978), teratogenicity (Javoraska, 1978) and phytotoxicity (Ismail, 2004).These factors emphasize the need for new methods to control diseases like "induced resistance" which is a promising modern approach with a broad spectrum in plant disease control (Ryals and Ward, 1994 and Meenakshi and Baldev, 2013).

The term "effective microorganisms (EM)" as proposed by Higa (1991) and Higa and Wididana (1991a), contains selected species of microorganisms including predominant populations of lactic acid bacteria and yeasts, and smaller numbers of photosynthetic bacteria, actinomycetes and other types of organisms such as mycorrhizae. Inoculation of EM cultures to the soil/plant ecosystem can improve soil quality, plant health, growth, yield and quality of crops. So, it added for optimizing best soil and crop management practices such as crop rotations, use of organic amendments, conservation tillage, crop residue recycling and biocontrol of pests. If used properly, EM can significantly enhance the beneficial effects of these practices (Higa and Wididana, 1991b).

Certain phytochemicals can be released from certain plants when decomposed either directly or indirectly to promote plant growth, yield and suppress diseases environmentally. Cabbage is one of these plants; it is known to have volatile compounds such as glucosinolates in their leaves, stems and roots, and it hydrolyzed to produce fungicidal isothiocyanolates (Karavina and Mandumba, 2012; Hansen and Keinath, 2013 and Omirou et al., 2013). Similarly, the biocidal properties of garlic and onion are attributed to sulphur volatiles produced during degradation of allium tissues. Allium spp. show fungicidal effects (Auger et al., 2002 and Auger et al., 2004). Combination of Allium cepea L. plus A. sativum L. extracts in conjunction with biocontrol agents, i.e. Pseudomonas fluorescens and Bacillus subtilis as bio-formulations reduced the early blight disease incidence (Latha et al., 2009).

There are many different types of inducers including microorganisms (fungi and bacteria), certain chemicals, plant extracts and even ultraviolet light (Obradovic and Jones, 2005), which can be used more safely than chemical. It may help in protecting plant against different types of diseases, caused by different kinds of pathogens (fungi, virus and bacteria). Furthermore, with the right inducer, it is possible to activate the defence in all cultivars of the plant, even the most susceptible (Sticher et al., 1997). Peroxidant chemicals were used to evaluate the hypotheses that localized oxidative damage, which culminates in necrosis, and then induce systemic acquired resistance (SAR) (Strobel and Kuc, 1995). The systemic acquired resistance (SAR) is a pathogen inducible defence mechanism that depends on 
salicylic acid (SA) and is associated with a system expression of a subset of defence genes, e.g. the acidic form of pathogenesis-related P R proteins (Sticher et al., 1997). Foliar application of hydroxyphaseolli (HP), on Vicia faba stimulates the formation of specific phytoalexins to each host, likewise in $V$. faba against chocolate spot disease caused by B. fabae (El-Hawa, 1998). Fortunately, induced resistance enhances growth parameters, chlorophyll content, plant growth, yields, accumulation of antifungal compounds and increases oxidative enzymes activity (Fariduddin et al., 2003).

This study consists of experimental sequence that aimed to formulate a new EM formula as "resistance inducer" to suppress the chocolate spot disease in faba bean and thus enhance its growth and productivity. This new EM formula contains EM1or EM5 as decomposers for cabbage, onion or garlic residues.

\section{Materials and Methods}

Source of Botrytis fabae and inoculum production:

Tested culture of B. fabae Sard. was provided from the culture collection of Dept. of Plant Protection, Desert Res. Centre. Inoculum was prepared by growing the isolate on faba bean dextrose agar medium (FDA) at $20^{\circ} \mathrm{C}$ for 10 days with $12 \mathrm{~h}$ photoperiod. For harvesting conidia, $10 \mathrm{ml}$ sterilized distilled water (SDW) were added to each plate and dislodged spores were filtered through 2 layers of muslin and centrifuged at $1000 \mathrm{~g}$ for $5 \mathrm{~min}$. The supernatant was removed and the pellet resuspended in 5-10 $\mathrm{ml}$ SDW by shaking for 20-30 sec., then the suspensions were diluted to $1 \times 10^{5}$ spores $\mathrm{ml}^{-1}$.

Preparation of tested inducers:

Crop residues of garlic, onion and cabbage (leaves mainly) were separately collected, and then air dried for thirty days away from direct sunlight. The residues were merged with hands then kept in tight bags in a cool and dry place until usage. EM1 and EM5 were kindly obtained from the EM Project, Ministry State of Environmental Affairs. Combination of either water or EM products and different dry weights of the crop residues were used for the experimental series within fermentation procedures for continuously forty days away from sunlight and under anaerobic conditions to formulate the examined biotic formulas. In the detached leaves, in vivo experiment ten ascending concentrations based on dry weight of each crop residue as $1 \%$ and up to $10 \%$ were used for fermentation in water, EM1 or EM5. Consequently, after the proper weight for each crop residue was selected, it was used to prepare different concentrations of each based on water, EM1 or EM5 biotic formula, i.e. $0,2,4,6,8$ and $10 \%$ for each crop residue to be examined under greenhouse conditions. As the microorganisms that existed in EM products extracted the active materials as inducers particularly EM1, yet within EM5 case the extraction happened either microbial as EM1, or biochemical through the biosolvents that existed in the product such as ethanol, vinegar, or esters that formed within the reaction between existed ethanol and vinegar. Concerning water (control) plant residues were kept in the water for forty days then percolate. Afterwards, the leached solution was used as stock solution as inducer. The proper two concentrations for each crop residue were used in the field experiments. 
In vivo bioassay of crop residues against B. fabae:

The detached leaves technique was used to determine the most dry matter weight of the examined plants; which decomposed in the various decomposers as inducer treatments against Botrytis fabae. Faba bean leaves were cut from 8-week old plants, surface sterilized by soaking in $2 \%$ chlorax solution for $1 \mathrm{~min}$, rinsed twice in distilled water and dried between filter papers before being placed abaxial surface uppermost in Petri dishes (15-cm-diam.) containing moist news-paper sheets. The cut ends of the petioles were wrapped with tissue paper to prevent desiccation. Leaves were sprayed with solutions as inducers that were prepared previously. After $24 \mathrm{~h}$., each leaflet was inoculated with $20 \mu \mathrm{L}$ droplets of spores of $B$. fabae $\left(10^{5}\right.$ spores $\left./ \mathrm{ml}^{-1}\right)$ and incubated at $18 \pm 2^{\circ} \mathrm{C}$ with $12 \mathrm{hrs}$. photoperiod under fluorescent lamp. Disease assessment was recorded according to the scale of Mansfield and Deverall (1974).

Greenhouse experiments:

Two experiments were carried out; the first was conducted prior to the field experiments; to evaluate the various concentrations of tested compounds as inducers $(2,4,6$ and $8 \%)$ on chocolate spot disease. Pots (25-cm-diam.) containing sandyloam soil were used and arranged in a randomized complete block design with three replicates. Seeds of $V$. faba (var. Giza 2) were disinfected in $2 \%$ (v/v) chlorax for $10 \mathrm{~min}$. followed by washing with sterile distilled water. Five seeds of faba bean were sown per pot. Thirty day after sowing date, plants were sprayed with solutions of the tested inducers as mentioned before. Two days later, the plants were infected by spraying $30 \mathrm{ml}$ of $B$. fabae, water spore suspension containing $\left(2.5 \times 10^{6}\right.$ spore $\mathrm{ml}^{-1}$ ) up to the first drop. Accordingly, left to be air dried, then sprayed with $15 \mathrm{ml}$ distilled water and covered with plastic bags for two hours to maintain high humidity atmosphere around the leaves which is necessary for fungal infection. The control treatment was only sprayed with $B$. fabae spore suspension.

After 45 days of sowing date, severity of chocolate spot was recorded and also some faba bean growth characters [plant height $(\mathrm{cm})$, plant fresh and dry weight $(\mathrm{g})$ and fourth leaf area $\left(\mathrm{cm}^{2}\right)$ ], total pigments using Minolta SPDA-502 leaf chlorophyll meter, were recorded then converted into total chlorophyll $(\mathrm{a}+\mathrm{b})$ as $\mu$ mole $\mathrm{m}^{-2}$ referring to the equation of John et al. (1988).

The second greenhouse experiment was carried out prior to the second field growing season (2010/11); to study the effect of the best various resistant inducers against chocolate spot disease associated with changes in faba bean enzymes activity and total phenol content. Pots (25-cm-diam.) containing five faba bean seeds per each in sandy-loam soil were arranged in a randomized complete block design with two replicates. Thirty days after sowing date, plants were sprayed with solutions of the tested inducer compounds as mentioned before. Plants were inoculated with Botrytis fabae spore suspension $\left(2.5 \times 10^{6}\right.$ spore $\left.\mathrm{ml}^{-1}\right)$. Accordingly, left to be air dried, then sprayed with $15 \mathrm{ml}$ distilled water and covered with plastic bags for two hours to maintain high humidity atmosphere around the leaves which is necessary for fungal infection. Samples were taken slightly from infected leaves at the time of inoculation, 24, 48 and $72 \mathrm{~h}$ after inoculation, to determine the changes in faba bean enzymes activity, while the total phenol content was determined after $72 \mathrm{~h}$ only.

Egypt. J. Phytopathol., Vol. 42, No. 1 (2014) 


\section{Disease assessment:}

Disease severity was calculated every 15 days using a scale ( 0 to 9$)$ that depended on the extent of lesions (Abou-Zeid, 1985), as the following the equation:

$$
\text { Disease severity }(\%)=\{(\mathrm{n} \times \mathrm{v}) /(\mathrm{g} \times \mathrm{n})\} \times 100
$$

Whereas: $\mathrm{n}=$ number of examined plants, $\mathrm{g}=$ maximum disease grade and $\mathrm{v}=$ disease grade.

The efficiency percentage (E\%) of each compound in reducing disease severity percentage in faba bean was assessed according to the equation adapted by Rewal and Jhooty (1985) as follows:

$\mathrm{E}(\%)=$ Disease severity $(\%)$ in control - disease severity $(\%)$ in treatment / disease severity $(\%)$ in control.

Determination of oxidative enzymes:

1- Enzymes Extraction:

Leaf samples from plants of each treatment growing under greenhouse conditions were collected at $0,24,48$ and 72 hrs. after challenge inoculation and used for determination of enzyme activity. Enzyme extracts were prepared according to Maxwell and Bateman (1967).

\subsection{Assay of peroxidase (PO) activity:}

Changes in peroxidase activity associated with the inducer treatments were determined following the procedure described by Sridhar and Ou (1974).

\subsection{Assay of polyphenoloxidase (PPO) activity:}

The activity of polyphenoloxidase was expressed as the change in absorbance/1.0 $\mathrm{ml}$ of extract per min at $495 \mathrm{m \mu}$ (Maxwell and Bateman, 1967).

Assay of total phenolic content:

Total phenolic contents were determined using the folin-ciocalteu reagent (Singleton and Rossi, 1965).

Field experiments:

Field experiments were conducted at 6 October Farm, Noubariya district, Behera Governorate, Egypt, during the two successive winter seasons of 2009/10 and 2010/11 to investigate the effect of spraying some biotic formulas based on effective microorganisms (EM) as inducers for faba bean growth, yield and chocolate spot disease resistance caused by B. fabae [EM1 4\%, EM1 8\%, (EM1+garlic 5\%) 4\%, (EM1+garlic 5\%) 8\%, (EM1+onion 5\%) 4\%, (EM1+onion $5 \%$ ) $8 \%$, (EM1+cabbage 10\%) 4\%, (EM1+cabbage 10\%) 8\%, EM5 4\%, EM5 8\%, (EM5+garlic 5\%) 4\%, (EM5+garlic 5\%) 8\%, (EM5+onion 5\%) 4\%, (EM5+onion $5 \%$ ) $8 \%$, (EM5+cabbage 10\%) 4\% and (EM5+cabbage 10\%) 8\%, where the control treatment was sprayed with tap water]. These biotic formulas were applied twice, i.e. 30 days and 60 days after sowing date. Plants were left for the natural infection by $B$. fabae as the area has experienced a long infection history with faba bean chocolate spot disease. 
EM1 consists of lactic acid bacteria, yeasts, photosynthetic bacteria, actinomycetes and mycorrhizae, while EM5 exceeded EM1 by Ethel alcohol and vinegar (Higa, 1991). To prepare the above mentioned biotic formulas, a precise weight of each examined plant, i.e. garlic, onion and cabbage, and referring to the results obtained from in vivo and greenhouse experiments were put in either EM1 or EM5 and incubated away from light and air continuously for forty days.

Soil samples were taken at depths of 30 and $60 \mathrm{~cm}$ for mechanical and chemical analysis (Table 1) as described by Chapman and Pratt (1978). During soil preparation, calcium superphosphate $\left(\begin{array}{lll}15.5 \% & \mathrm{P}_{2} \mathrm{O}_{5}\end{array}\right)$ was added at the rate of $200 \mathrm{~kg} / \mathrm{fed}$. and potassium sulphate $\left(48 \% \mathrm{k}_{2} \mathrm{O}\right)$ was added to soil just after thinning in the rate of $50 \mathrm{~kg} / \mathrm{fed}$., while nitrogen fertilization was added at two equal doses, i.e. $48 \mathrm{~kg} / \mathrm{fed}$ in the form of ammonium nitrate $(33.5 \% \mathrm{~N})$ after thinning $(21$ days after sowing date) and after the second irrigation.

Table 1. Mechanical and chemical analysis of the experimental soils at 30 and $60 \mathrm{~cm}$ during 2009/10 and 2010/11 seasons

\begin{tabular}{|l|r|r|r|r|}
\hline \multirow{2}{*}{ Analysis } & \multicolumn{2}{c|}{$2009-2010$} & \multicolumn{2}{c|}{$2010-2011$} \\
\cline { 2 - 5 } & $30 \mathrm{~cm}$ & $60 \mathrm{~cm}$ & $30 \mathrm{~cm}$ & $60 \mathrm{~cm}$ \\
\hline Mechanical analysis: & \multicolumn{4}{c|}{} \\
\hline Sand \% & 91.2 & 93.7 & 92.33 & 93.12 \\
\hline Silt \% & 3.7 & 3.9 & 2.95 & 3.12 \\
\hline Clay \% & 5.1 & 3.4 & 4.78 & 3.76 \\
\hline Soil texture & Sandy & sandy & sandy & sandy \\
\hline Chemical analysis: & 0.3 & 0.3 & 0.5 & 0.7 \\
\hline E.C. mmohs/cm ${ }^{3}$ & 24.8 & 18.2 & 22.3 & 16.8 \\
\hline Organic matter \% & 8.1 & 9.2 & 7.45 & 8.25 \\
\hline Soluble N ppm & 3.2 & 3.6 & 4.12 & 4.65 \\
\hline Available P ppm & 20.0 & 23.5 & 26.0 & 24.55 \\
\hline Exchange K ppm &
\end{tabular}

Faba bean seeds (Giza 2) were sown in October $1^{\text {st }}$ on ridges $60 \mathrm{~cm}$ apart in both winter seasons at the rate $60 \mathrm{~kg}$ seeds/fed., using 2-3 seeds/hill, with $25 \mathrm{~cm}$ apart on one side of ridge, and thinned to one plant/hill, three weeks after sowing date. Treatments were arranged in split plot design with three replicates, where the time of application occupied the main plots and the biotech formulas occupied the sub-plots. The plot area was $10 \mathrm{~m} 2(3 \times 3.5 \mathrm{~m})$ including 5 ridges.

Samples were taken from ten guarded plants per each plot after 10 days from applying the treatments to study some growth characters, i.e. plant height $(\mathrm{cm})$, plant fresh and dry weight $(\mathrm{g})$ and fourth leaf area $(\mathrm{cm} 2)$, total pigments using Minolta SPDA-502 leaf chlorophyll meter, then converted into total chlorophyll $(a+b)$ as $\mu$ mole m-2 referring to the equation published by John et al. (1988) in addition to incidence of chocolate spot disease. At harvest, yield and its components were evaluated, i.e. biological, seed and straw yields (ton/fed.), number of branches/plant, and weight of 100 seeds $(\mathrm{g})$. 
Weeds control was carried out, two weeks after sowing date, by hand pulling and by hoeing three weeks later. However, the common agricultural practices for growing faba bean plants were applied.

Obtained data were exposed to the statistical analysis according to procedure outlined by Snedecor and Cochran (1980), while L.S.D. test at 5\% level was used to differentiate between treatments means, according to Steel and Torrie (1960).

\section{R e s u l t s}

Efficacy of the most appropriate dry matter weight for the examined plants that decomposed by the various decomposers as inducer treatments for suppression of chocolate spot in vivo:

Results illustrated in Figs. (1 and 2) indicate that in faba bean detached leaves $(20 \mu 1)$ inoculum droplets which contained 2000 B. fabae conidia developed lesion after the inoculation, while browning of inoculum sites was increased rapidly forming a dark brown to black spreading lesion on the control plants. Plants dry matter weights seemed to be vary in their ability to reduce chocolate spot lesion on detached leaves, thus caused slightly red small lesions with dry matter weights ( $5 \mathrm{~g}$ for onion or garlic and $10 \mathrm{~g}$ for cabbage that decomposed in either EM1or EM5), while black gray spreading lesions were obtained with plants dry matter weights (1-4g onion or garlic and $1-9 \mathrm{~g}$ for cabbage that decomposed in all used decomposers). At the higher weights of plant dry matter above $5 \mathrm{~g}$ for onion and garlic black burn leaves edges were obtained. It was concluded that $5 \mathrm{~g}$ dry matter for onion or garlic and $10 \mathrm{~g}$ dry matter for cabbage which decomposed in either EM1 or EM5 to formulate the different "biotic formulas" gave the most effective browning lesion reduction and spreading.

Evaluation of the examined biotic formulas concentrations on faba bean chocolate spot disease incidence and some growth characters under greenhouse conditions:

As shown in Fig. (3), 4\% indicated remarkable disease severity and spreading reduction. The reduction efficiency curve was stable at 6,8 and $10 \%$ concentrations. Higher disease reduction was obtained by spraying the biotic formula (garlic+EM5) at the concentration $8 \%$ followed by the biotic formula (garlic+EM1) and (onion+EM5) at 4, 6, 8 and $10 \%$ concentrations, respectively.

Concerning faba bean growth characters, results illustrated in Fig. (4) indicate that in general; spraying the different biotic formulas with different concentrations onto faba bean plants led to increase all the studied growth characters, i.e. plant height, fresh and dry weight in addition to total pigments and chlorophyll content. The used decomposers seemed to be varied significantly in their capability for active materials extraction from the decomposed plants, thus enhanced faba bean studied growth characters. It was clear that higher values were obtained from EM5 followed by EM1 then water, respectively. Concerning the biotic formulas concentrations, both plant height and fresh weight were increased significantly with increasing the biotic formulas concentrations up to $10 \%$. Yet, plant dry weight, total pigments and chlorophyll content were increased significantly up to $8 \%$ then declined at $10 \%$ concentration. 


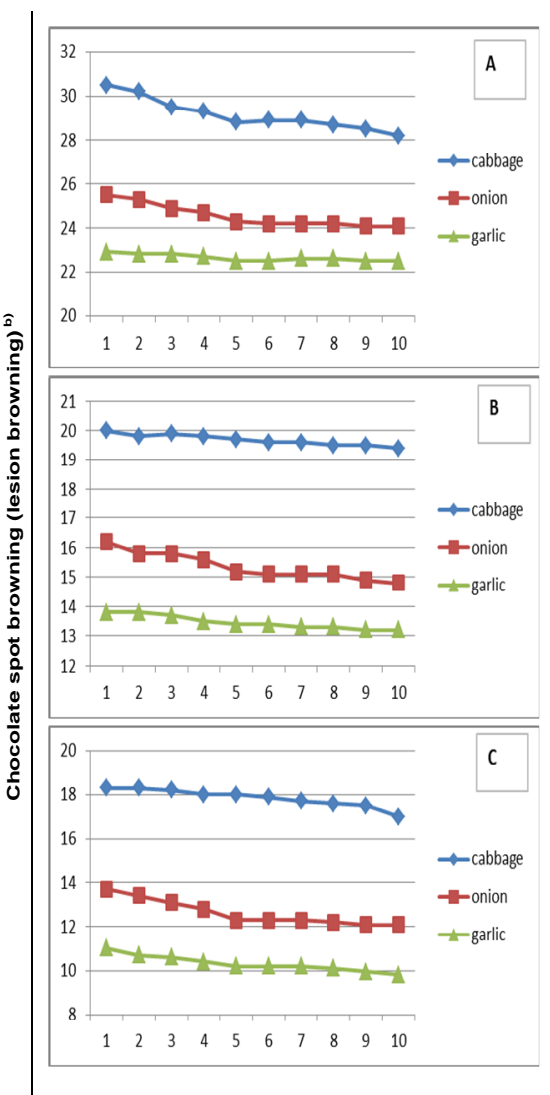

Plant inducers concentration as (dry matter \%)

Fig. 1. Suppression of chocolate spot lesions on detached broad bean leaves treated with different plants decomposed in $(A=$ water, $B=$ EM1 and $\mathrm{C}=$ EM5) and challenged with B. fabae conidia ${ }^{\mathrm{a}}$.

a) Inoculum droplets, $20 \mu$ each of $B$. fabae containing 2000 conidia were used for inoculation of each site.

b) Percentage of browning beneath the inoculum droplet.

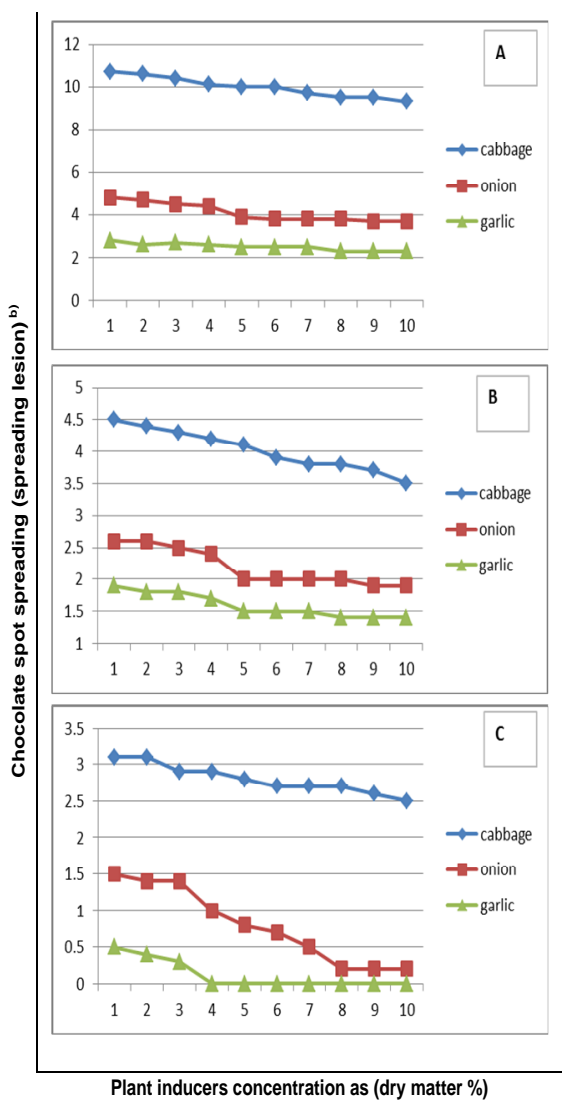

Fig. 2. Suppression of chocolate spot lesions on detached broad bean leaves treated with different plants decomposed in $(A=$ water, $B=$ EM1 and $\mathrm{C}=$ EM5) and challenged with B. fabae conidia .

a) Inoculum droplets, $20 \mu$ each of $B$. fabae containing 2000 conidia were used for inoculation of each site.

b) Percentage of spreading lesion beneath the inoculum droplet. 


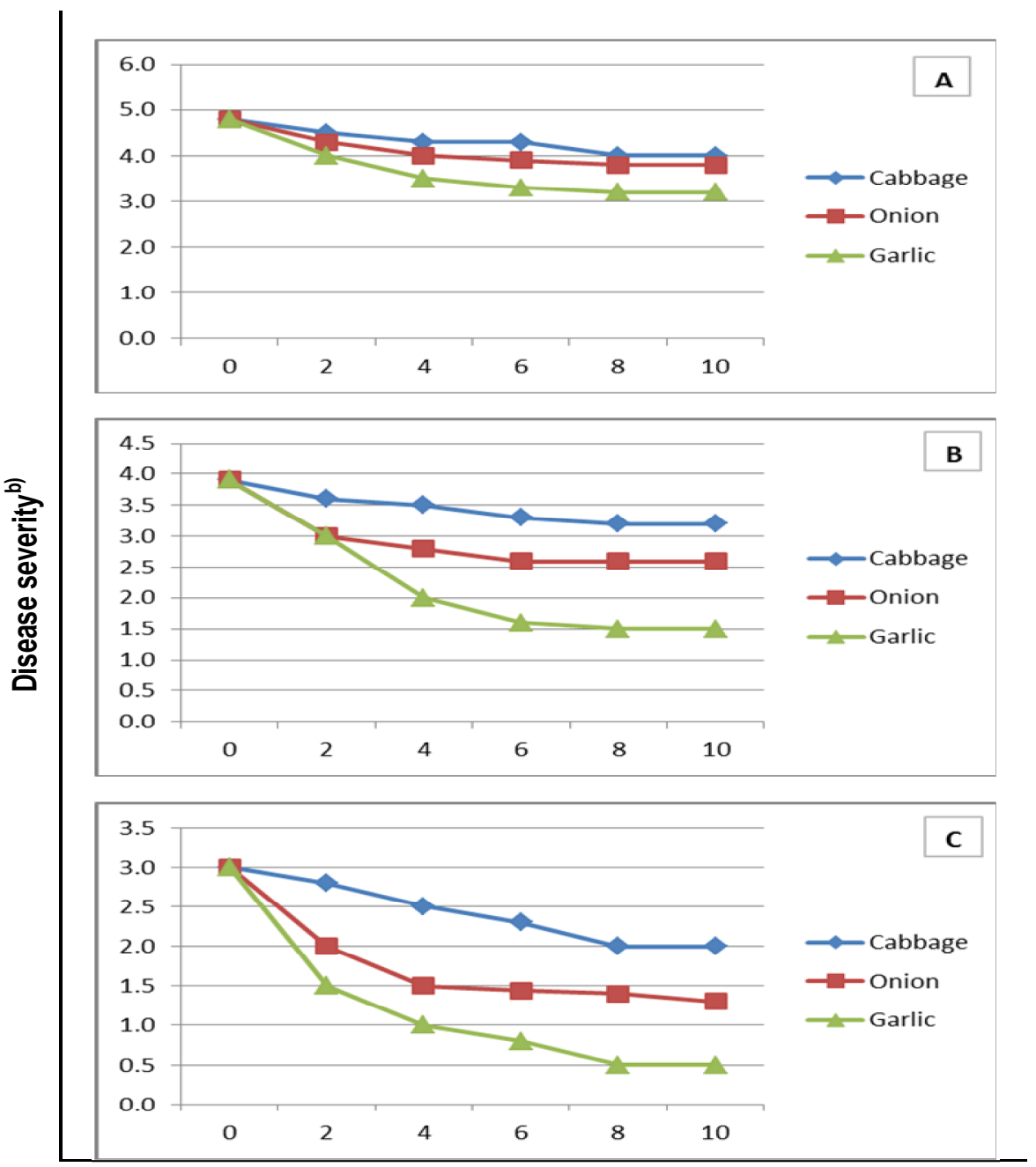

Concentration of decomposition solutions \%

Fig. 3. Screening of different solutions concentrations (\%) of different plants decomposed in $(A=$ Water, $B=E M 1, C=E M 5)$ as biotic formulas against faba bean chocolate spot disease incidence ${ }^{a}$ at $\mathbf{4 0}$ days from sowing date, under greenhouse conditions.

a) Plants were sprayed up to the first drop with every concentration of each decomposed solution after 30 days from sowing date.

b) Disease severity was assessed using the scale described by Anonymous (1976). 


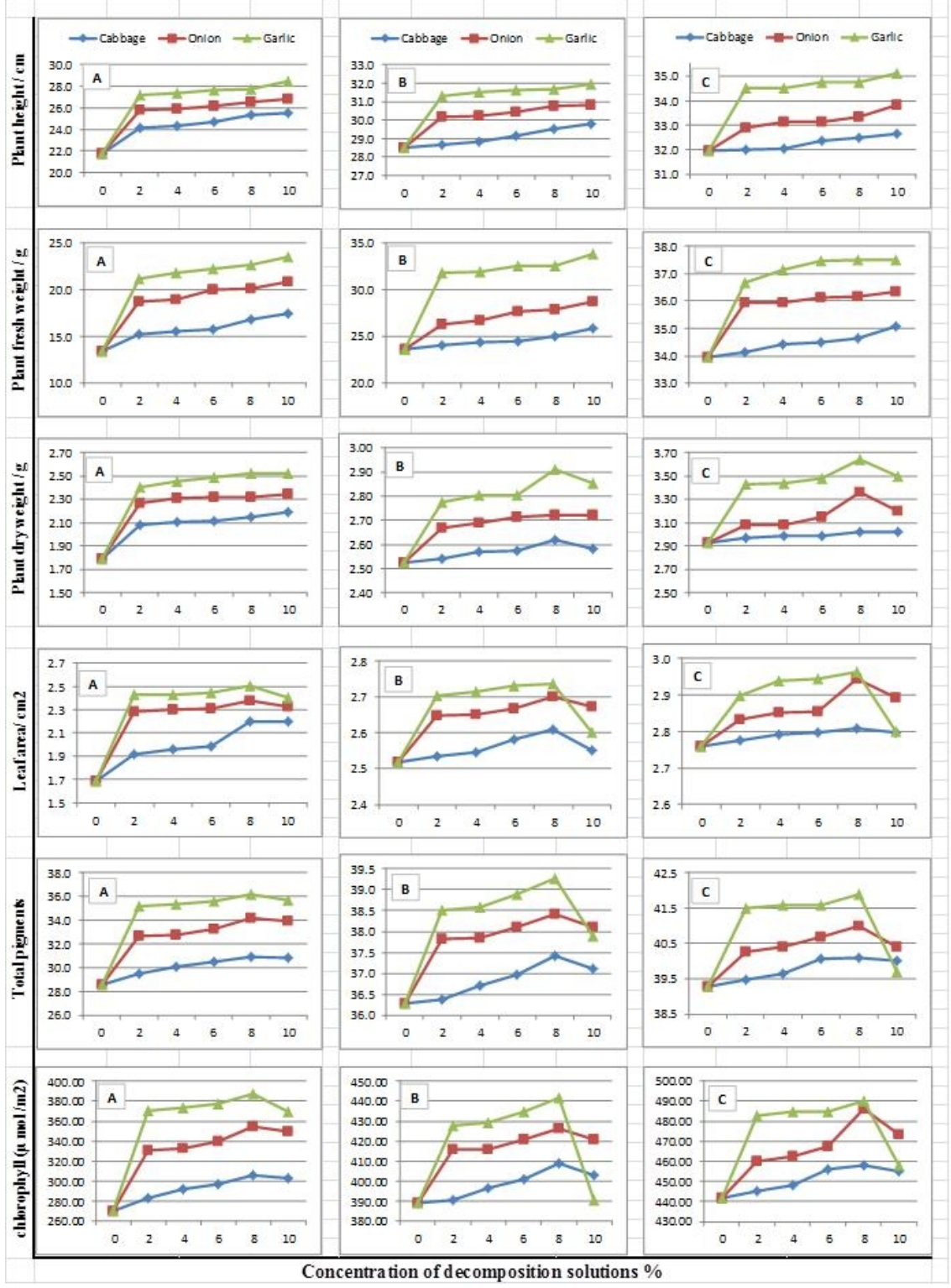

Fig.4. Screening of some faba bean growth \& chemical characters at 40 days after sowing date, as affected by foliar spraying with different solutions concentrations $(\%)$ of different plants decomposed in $(A=$ Water, B= EM1, C= EM5) as biotic formulas under greenhouse conditions. 
It was concluded that the overall positive response curve began at the concentration $4 \%$ then ended at $8 \%$ for all the examined biotic formulas that increased faba bean disease resistance and enhanced total chlorophyll and pigments content and growth characters. Therefore, 4 and $8 \%$ seemed to be the most appropriate concentrations to be used under field conditions.

Field experiments:

Six promising biotic formulas with two concentrations were selected to be evaluated under field conditions out of all the examined formulas concentrations which had passed all the evaluation procedures.

Chocolate spot disease severity as affected by time of application with biotic formulas as inducers:

Results in Tables (2 and 3) indicate that spraying the biotic formulas as inducers at 30 or 60 days from sowing date onto faba bean; suppressed the chocolate spot disease severity. Disease suppression was significantly greater in the first season more than the second. It could be concluded that in order to obtain the most effective and significant disease severity suppression; the biotic formulas should be applied onto faba bean at 30 days from sowing date rather than at 60 days.

Chocolate spot disease severity as affected by application with different concentrations of biotic formulas as inducers:

Results in Tables (2 and 3) indicate that in the two growing seasons chocolate spot disease severity was reduced significantly by applying the examined biotic materials at the concentrations 4 and $8 \%$, respectively. The biotic formulas that contained EM5 as decomposer led to significant disease severity suppression more than that contained EM1 or water "control treatment", respectively. Robust disease suppression that remained up to 90 days; was obtained by applying the formulas (EM5+garlic) at the concentration 8\%, (EM5+garlic) 4\%, (EM5+onion) 8\% and (EM1+garlic) 8\%, respectively. Consequently, significant moderate disease suppression was obtained by applying the biotic formulas (EM5+onion) 4\%, (EM1+garlic) 8\%, (EM5+cabbage) $8 \%$ and (EM1+cabbage) 8\%, respectively. It could be concluded that foliar application with biotic formula (EM5+garlic) at concentration $8 \%$ was the best to suppress the disease severity.

Chocolate spot disease severity as affected by the interaction between time of application and biotic formulas concentrations as inducers:

The same trend was obtained when the results presented in the Tables (2 and 3) were compared together. At 30 days from sowing date, the most promising biotic formula was (EM5+garlic) at the concentration 8\%, (EM5+garlic) 4\%, (EM5+onion) $8 \%$ and (EM1+garlic) 8\%, respectively. Similarly, significant moderate disease suppression was obtained by applying the biotic formulas (EM5+onion) 4\%, (EM1+garlic) 8\%, (EM5+cabbage) 8\% and (EM1+cabbage) 8\%, respectively. At 60 days after sowing date, (EM5+garlic) at the concentration 8\%, followed by (EM5+garlic) 4\%, (EM1+garlic) 8\% and (EM5+onion) 8\%, respectively gave the robust disease suppression, while the moderate one was obtained from applying (EM1+garlic) 4\%, (EM5+onion) 4\%, respectively. It could be concluded that at 30 and 60 days from sowing, foliar application with (EM5+ garlic) $8 \%$ was the best to suppress the disease severity. 
Table 2. Effect of foliar spraying with some plant extracts decomposed in EM1 or EM5 as biotic formulas on the incidence of chocolate spot disease of Vicia faba L. (Giza 2) under field conditions

\begin{tabular}{|c|c|c|c|c|c|c|c|c|c|}
\hline \multirow{4}{*}{ 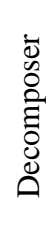 } & \multirow{4}{*}{$\begin{array}{c}\text { Treatment } \\
\text { concentration }^{\mathrm{a}}\end{array}$} & \multicolumn{4}{|c|}{$1^{\text {st }}$ growing season } & \multicolumn{4}{|c|}{$2^{\text {nd }}$ growing season } \\
\hline & & \multicolumn{4}{|c|}{ Days after sawing date } & \multicolumn{4}{|c|}{ Days after sawing date } \\
\hline & & \multicolumn{2}{|c|}{45} & \multicolumn{2}{|c|}{75} & \multicolumn{2}{|c|}{45} & \multicolumn{2}{|c|}{75} \\
\hline & & D.S $S^{c}$ & $\mathrm{E} \%{ }^{\mathrm{d}}$ & D.S & $\mathrm{E} \%$ & D.S & $\mathrm{E} \%$ & D.S & $\mathrm{E} \%$ \\
\hline & Water $^{\mathrm{b}}$ & 2.6 & & 20.0 & & 3.17 & & 22.2 & \\
\hline \multirow{8}{*}{$\sum_{I I}$} & Alone $4 \%$ & 1.9 & 26.9 & 14.6 & 27.0 & 2.30 & 27.4 & 18.0 & 18.9 \\
\hline & Alone $8 \%$ & 1.43 & 45.0 & 13.5 & 32.5 & 1.83 & 42.3 & 15.6 & 29,7 \\
\hline & Cabbage $4 \%$ & 1.37 & 46.3 & 13.7 & 31.5 & 1.77 & 44.2 & 14.9 & 32.9 \\
\hline & Cabbage $8 \%$ & 1.27 & 51.2 & 12.5 & 37.5 & 1.63 & 48.6 & 14.5 & 34.7 \\
\hline & Onion $4 \%$ & 1.07 & 58.4 & 11.9 & 40.5 & 1.53 & 51.7 & 14.0 & 36.9 \\
\hline & Onion $8 \%$ & 0.8 & 69.2 & 11.1 & 44.5 & 1.33 & 58.0 & 13.6 & 38.7 \\
\hline & Garlic $4 \%$ & 0.73 & 71.9 & 10.8 & 46.0 & 1.23 & 61.2 & 13.4 & 39.9 \\
\hline & Garlic $8 \%$ & 0.53 & 79.6 & 10.3 & 48.5 & 1.23 & 61.2 & 12.7 & 42.8 \\
\hline \multirow{8}{*}{$\sum_{[I I}^{n}$} & Alone $4 \%$ & 1.47 & 43.4 & 12.8 & 36.0 & 1.63 & 48.6 & 14.4 & 35.1 \\
\hline & Alone $8 \%$ & 1.17 & 55.0 & 11.5 & 42.5 & 1.57 & 50.5 & 13.5 & 39.2 \\
\hline & Cabbage $4 \%$ & 1.1 & 57.7 & 11.3 & 43.5 & 1.33 & 58.0 & 13.2 & 40.5 \\
\hline & Cabbage $8 \%$ & 0.9 & 65.4 & 10.5 & 47.5 & 1.1 & 65.3 & 12.7 & 42.8 \\
\hline & Onion $4 \%$ & 0.7 & 73.1 & 9.9 & 50.5 & 0.83 & 73.8 & 11.7 & 47.3 \\
\hline & Onion $8 \%$ & 0.47 & 81.9 & 9.6 & 52.0 & 0.63 & 80.1 & 11.0 & 50.5 \\
\hline & Garlic $4 \%$ & 0.37 & 85.8 & 8.8 & 56.0 & 0.67 & 78.9 & 10.3 & 53.6 \\
\hline & Garlic $8 \%$ & 0.0 & 100.0 & 6.8 & 66.0 & 0.37 & 88.3 & 9.3 & 58.1 \\
\hline \multicolumn{2}{|r|}{ LSD at 0.05} & 0.14 & - & 0.42 & - & 0.199 & - & 0.460 & - \\
\hline
\end{tabular}

- Plants were sprayed up to the first drop with biotic formulas once 30 days after sowing date. a) Cabbage 10\%, onion+garlic 5\% residues were decomposed in (EM1) or (EM5) 4 and $8 \%$.

b) Plants were sprayed with tap water as control treatment.

c) Disease severity was assessed using the scale described by Abou-Zeid (1985).

d) Efficacy percentage of each compound in reducing disease severity was assessed according to the equation adapted by Rewal and Jhooty (1985). 
Table 3. Effect of foliar spraying with some plant extracts decomposed in EM1 or EM5 as biotic formulas on the incidence of chocolate spot disease of faba bean (Giza 2) under field conditions in two seasons

\begin{tabular}{|c|c|c|c|c|c|c|c|c|c|}
\hline \multirow{4}{*}{ 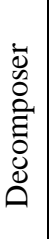 } & \multirow{4}{*}{$\begin{array}{c}\text { Treatment } \\
\text { concentration }^{\mathrm{a}}\end{array}$} & \multicolumn{4}{|c|}{$1^{\text {st }}$ growing season } & \multicolumn{4}{|c|}{$2^{\text {nd }}$ growing season } \\
\hline & & \multicolumn{4}{|c|}{ Days after sowing date } & \multicolumn{4}{|c|}{ Days after sowing date } \\
\hline & & \multicolumn{2}{|c|}{75} & \multicolumn{2}{|c|}{90} & \multicolumn{2}{|c|}{75} & \multicolumn{2}{|c|}{90} \\
\hline & & D. $S^{c}$ & $\mathrm{E} \%{ }^{\mathrm{d}}$ & D.S & $\mathrm{E} \%$ & D.S & $\mathrm{E} \%$ & D.S & $\mathrm{E} \%$ \\
\hline & Water $^{\mathrm{b}}$ & 20.5 & & 21.7 & & 22.5 & & 23.0 & \\
\hline \multirow{8}{*}{$\sum_{\text {II }}$} & Alone 4\% & 17.0 & 17.1 & 17.5 & 19.4 & 18.9 & 16.0 & 19.5 & 15.2 \\
\hline & Alone $8 \%$ & 15.6 & 23.9 & 16.0 & 26.3 & 17.4 & 22.7 & 18.0 & 12.7 \\
\hline & Cabbage $4 \%$ & 15.1 & 26.3 & 15.5 & 28.6 & 16.9 & 24.9 & 17.2 & 25.2 \\
\hline & Cabbage $8 \%$ & 14.5 & 29.3 & 15.5 & 28.6 & 16.3 & 27.6 & 16.5 & 28.3 \\
\hline & Onion $4 \%$ & 13.8 & 32.7 & 14.0 & 35.5 & 14.8 & 34.2 & 15.0 & 34.8 \\
\hline & Onion $8 \%$ & 13.0 & 36.6 & 13.5 & 37.8 & 14.2 & 36.9 & 14.5 & 37.0 \\
\hline & Garlic 4\% & 12.6 & 38.5 & 13.0 & 40.1 & 15.6 & 30.7 & 15.7 & 31.7 \\
\hline & Garlic $8 \%$ & 12.1 & 41.0 & 12.4 & 42.9 & 15.3 & 32.0 & 13.0 & 43.5 \\
\hline \multirow{8}{*}{$\sum_{i=1}^{n}$} & Alone $4 \%$ & 15.1 & 26.3 & 15.4 & 29.0 & 16.3 & 27.6 & 16.5 & 28.3 \\
\hline & Alone $8 \%$ & 14.2 & 30.7 & 14.3 & 34.1 & 15.7 & 30.0 & 16.0 & 30.4 \\
\hline & Cabbage $4 \%$ & 13.9 & 32.2 & 14.0 & 35.5 & 16.2 & 28.0 & 16.5 & 28.3 \\
\hline & Cabbage $8 \%$ & 13.4 & 34.6 & 13.5 & 37.8 & 14.3 & 36.4 & 14.5 & 37.0 \\
\hline & Onion $4 \%$ & 12.7 & 38.4 & 12.5 & 24.4 & 12.6 & 44.0 & 12.7 & 44.8 \\
\hline & Onion $8 \%$ & 12.1 & 41.0 & 12.0 & 44.7 & 11.9 & 47.1 & 12.0 & 47.8 \\
\hline & Garlic 4\% & 11.3 & 44.9 & 11.0 & 49.3 & 13.2 & 41.3 & 13.0 & 43.5 \\
\hline & Garlic $8 \%$ & 10.0 & 51.2 & 10.2 & 53.0 & 12.3 & 45.3 & 12.0 & 47.8 \\
\hline \multicolumn{2}{|r|}{ LSD at 0.05} & 0.32 & & 0.40 & & 1.5 & & 1.6 & \\
\hline
\end{tabular}

- Plants were sprayed up to the first drop with biotic formulas once 60 days after sowing date. - $a, b, c$ and d: As described in footnote of Table (2). 
Plant growth characters, total chlorophyll, pigments, yield and its attributes as affected by time of application with biotic formulas as inducers:

Results presented in Tables (4 and 5) indicate that during the two experimental seasons, foliar application with the biotic formulas as inducers significantly increased all faba bean studied characters, i.e. plant height, plant fresh and dry weight, $4^{\text {th }}$ leaf area, total pigments and chlorophyll content, number of branches/plant, weight of 100 seeds and biological, seed and straw yields. In addition, biotic formulas application at 30 days from sowing date led to significant increase in all the above mentioned studied characters more than application at 60 days. Nevertheless, the first year observations were higher than the second. It could be concluded that in order to obtain a remarkable faba bean growth characters correlated with appreciated yield the examined biotic formulas as inducers should be applied at 30 days from sowing date.

Plant growth characters, total chlorophyll, pigments, yield and its attributes as affected by application with different concentrations of biotic formulas as inducers:

Results presented in Tables (6 and 7) indicate that in comparison to water as the control treatment; foliar application of the biotic formulas that contained EM5 followed by that contained EM1 led to increase significantly all the studied growth characters and even more than EM5 and EM1 alone, respectively. Similarly, the biotic formulas with $8 \%$ concentration significantly surpassed that with $4 \%$. Highest significant records were obtained from the application of the formulas; (EM5+garlic) $8 \%$, (EM5+garlic) 4\%, (EM5+onion) 8\%, and (EM5+onion) 4\%, respectively. Results in Table (8) indicate that at both growing seasons the highest yield and its attributes were obtained from the foliar application with the biotic formulas as inducers; (EM5+garlic) 4\%, (EM5+onion) 8\%, (EM5+onion) 4\% followed by (EM5+cabbage) 8\%, respectively. It could be concluded that in order to obtain a notable faba bean growth characters that correlated with an appreciated yield; one of the following biotic formulas as inducers; (EM5+garlic) 4\%, (EM5+onion) $8 \%$, (EM5+onion) $4 \%$ or (EM5+cabbage) $8 \%$, respectively, should be applied.

Growth characters, yield and its attributes as affected by the interaction between time of application and biotic formulas concentrations as inducers:

Despite all the observed results at the interaction levels were not significant, yet the significant responses in plant height, plant dry weight, total chlorophyll and pigments in addition to weight of 100 seeds and seed yield were only obtained from the following biotic formulas: at 30 days after sowing date (EM5+garlic) 4\% and (EM5+onion) 8\%, while at 60 days after sowing date (EM5+garlic) 8\% was the only treatment which gave significant responses in plant height, plant dry weight, total pigments, weight of 100 seeds and seed yield. It could be concluded that at 30 days after sowing date the foliar application of one of the following biotic formulas as inducers: (EM5+garlic) 4\% and (EM5+onion) 8\% will result in noteworthy plant growth accompanied with an appreciated yield. Likewise, at 60 days after sowing date only (EM5+ garlic) $8 \%$ is recommended. 
Table 4. Effect of application time of foliar spraying with some plant extracts decomposed in EM1 or EM5 as biotic formulas on faba bean (Giza 2) growth and pigments content during two growing seasons

\begin{tabular}{|l|c|c|c|}
\hline \multirow{2}{*}{ Character } & \multicolumn{2}{c}{$\begin{array}{c}\text { Date of application } \\
\text { (Days after sowing date) }\end{array}$} & \multirow{2}{*}{ LSD at 5\% } \\
\cline { 2 - 3 } & 30 days & 60 days & \\
\hline \multicolumn{2}{|c|}{$1^{\text {st }}$ growing season $(2009 / 10)$} \\
\hline Plant height $(\mathrm{cm})$ & $69.71^{*}$ & 66.09 & 0.26 \\
\hline Plant fresh weight $(\mathrm{g})$ & 65.56 & 61.91 & 0.18 \\
\hline Plant dry weight $(\mathrm{g})$ & 6.79 & 6.44 & 0.02 \\
\hline $4^{\text {th }}$ Leaf area $\left(\mathrm{cm}^{2}\right)$ & 5.98 & 5.67 & 0.02 \\
\hline Total pigments & 46.70 & 44.90 & 0.06 \\
\hline Chlorophyll $(\mu \mathrm{mol} / \mathrm{m} 2)$ & 597.00 & 556.90 & 2.69 \\
\hline \multicolumn{2}{|l|}{$2^{\text {nd }}$ growing season $(2010 / 11)$} & \\
\hline Plant height $\left(\mathrm{cm}^{2}\right)$ & 56.90 & 53.76 & 1.62 \\
\hline Plant fresh weight $(\mathrm{g})$ & 60.55 & 56.98 & 1.94 \\
\hline Plant dry weight $(\mathrm{g})$ & 6.13 & 5.81 & 0.23 \\
\hline $4^{\text {th }}$ Leaf area $\left(\mathrm{cm}^{2}\right)$ & 5.11 & 4.83 & 0.16 \\
\hline Total pigments & 44.13 & 42.22 & 1.26 \\
\hline Chlorophyll $(\mu \mathrm{mol} / \mathrm{m} 2)$ & 543.00 & 503.30 & 2.70 \\
\hline
\end{tabular}

* Data were recorded 75 days after sowing date.

Table 5. Effect of application time of foliar spraying with some plant extracts decomposed in EM1 or EM5 as biotic formulas on faba bean (Giza 2) yield and its attributes at harvest time

\begin{tabular}{|c|c|c|c|}
\hline \multirow[t]{2}{*}{ Character } & \multicolumn{2}{|c|}{$\begin{array}{c}\text { Date of application } \\
\text { (Days after sowing date) }\end{array}$} & \multirow[t]{2}{*}{ LSD at $5 \%$} \\
\hline & 30 days & 60 days & \\
\hline \multicolumn{4}{|c|}{$1^{\text {st }}$ growing season $(2009 / 10)$} \\
\hline No. of branches / plant & 3.98 & 3.53 & 0.20 \\
\hline Weight of 100 seeds $(\mathrm{g})$ & 47.19 & 42.05 & 2.35 \\
\hline Bio. yield (ton/fed $\left.{ }^{-1}\right)$ & 2.94 & 2.62 & 0.15 \\
\hline Seed yield (ton/fed $\left.{ }^{-1}\right)$ & 1.17 & 1.04 & 0.06 \\
\hline Straw yield $\left(\right.$ ton $\left./ \mathrm{fed}^{-1}\right)$ & 1.77 & 1.58 & 0.09 \\
\hline \multicolumn{4}{|c|}{$2^{\text {nd }}$ growing season $(2010 / 11)$} \\
\hline No. of branches / plant & 3.65 & 3.27 & 0.18 \\
\hline Weight of 100 seeds $(\mathrm{g})$ & 43.27 & 38.91 & 2.11 \\
\hline Bio. yield (ton $\left./ \mathrm{fed}^{-1}\right)$ & 2.70 & 2.43 & 0.14 \\
\hline Seed yield (ton/fed $\left.{ }^{-1}\right)$ & 1.07 & 0.96 & 0.05 \\
\hline Straw yield $\left(\right.$ ton $/$ fed $\left.^{-1}\right)$ & 1.63 & 1.47 & 0.08 \\
\hline
\end{tabular}


Table 6. Effect of foliar spraying 30 days after sowing date with some plant extracts decomposed in EM1 or EM5 as biotic formulas on faba bean (Giza 2) growth characters, pigments and chlorophyll content during two growing seasons

\begin{tabular}{|c|c|c|c|c|c|c|c|c|c|c|c|c|c|}
\hline \multirow[b]{3}{*}{ 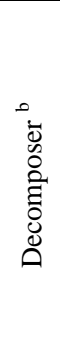 } & \multirow[b]{3}{*}{ 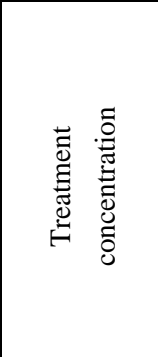 } & \multicolumn{6}{|c|}{$1^{\text {st }}$ growing season $(2009 / 10)$} & \multicolumn{6}{|c|}{$2^{\text {nd }}$ growing season $(2010 / 11)$} \\
\hline & & \multicolumn{12}{|c|}{ Character $^{\mathrm{a}}$} \\
\hline & & 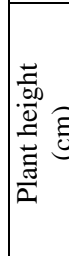 & 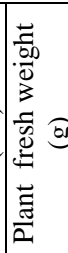 & 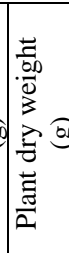 & 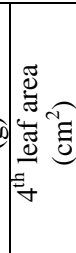 & 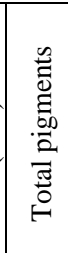 & 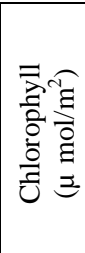 & 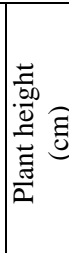 & 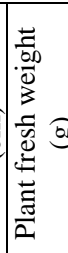 & 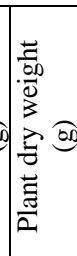 & 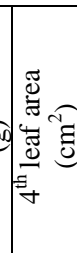 & 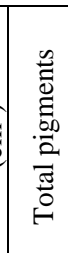 & 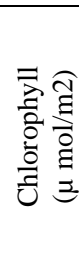 \\
\hline & & 6 & 3.7 & 2 & 2.33 & .1 & 24.0 & 9.1 & 23.2 & 64 & 2.10 & 24.6 & 17.6 \\
\hline \multirow{8}{*}{$\sum_{I I}$} & me & 31.3 & 24.7 & 3.03 & 2.53 & 26.0 & 236.1 & 29.7 & 24.2 & 2.91 & 2.27 & 25.5 & 229.3 \\
\hline & c & 3 & 30.1 & 3.14 & 2.83 & 2 & 240 & 30.4 & 29.5 & 01 & 2.27 & 2 & 4 \\
\hline & & 32.7 & 30.2 & 3 & 2.87 & 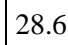 & 4 & 31.1 & 9.5 & 6 & 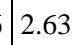 & 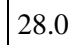 & 262 \\
\hline & Gar & .7 & 33.0 & 3.44 & 2.87 & 28.9 & 293.1 & 32.0 & 32.4 & 3.30 & 2.63 & 29.2 & 284.3 \\
\hline & & & 9 & 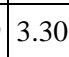 & 3.07 & 0.4 & 97.3 & 32.4 & 3.2 & 3.17 & 2.77 & 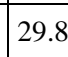 & 88 \\
\hline & & .6 & 39.0 & 3 & 3.07 & 30.8 & 302.8 & 32.9 & 38.2 & 3.17 & 2.77 & 30.2 & 293.7 \\
\hline & & 9 & 39.1 & 3.55 & 3.17 & & 307.0 & 33.2 & 38.3 & 3.40 & 2.87 & 30.4 & 297.8 \\
\hline & & 3 & 44.2 & 3.56 & 3.17 & 31.6 & 315.5 & 33.4 & 43.3 & 3.42 & 2.87 & 31.0 & 305.9 \\
\hline \multirow{8}{*}{$\sum_{i=1}^{n}$} & A & .8 & 54.6 & 3.63 & 3.27 & 2.7 & 331.3 & 32.3 & 53.5 & 3.48 & 2.97 & 32.0 & 321.2 \\
\hline & & & & & & & 3.6 & 5.3 & 4.2 & .79 & 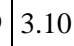 & & 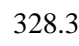 \\
\hline & & & .5 & 4 & 3 & & .6 & 9.1 & 5.3 & 95 & 17 & & 330.9 \\
\hline & Garlic 4\% & 9 & .3 & 4 & 3 & & .5 & 39.8 & 6.2 & 57 & 3.17 & 3 & 339.1 \\
\hline & Alo & .7 & 57.7 & 5.30 & 3.63 & 34.2 & 355.1 & 41.5 & 56.5 & 5.09 & 3.27 & 3. & 34 \\
\hline & $\mathrm{Ca}$ & & 59.7 & 5.36 & 3.63 & & 364.2 & 41.7 & 58.5 & 5.14 & 3.27 & 3 & 352 \\
\hline & $\mathrm{Ol}_{1}$ & 45 & 62.6 & 6.61 & 3.93 & 59.5 & 443.4 & 43.0 & 31.4 & 6.34 & 3.53 & 38.5 & 429.2 \\
\hline & Garlic & & 2.2 & 5 & 3 & & 407. & 42.4 & 60.9 & 35 & 3.37 & 13 & 355.8 \\
\hline \multicolumn{2}{|r|}{ LSD at 0.05} & 2.56 & 3.80 & 0.48 & 0.21 & 3.11 & 57.1 & 2.62 & 3.72 & 0.47 & $\begin{array}{ll}7 & 0.17\end{array}$ & 3.71 & 55.1 \\
\hline
\end{tabular}

a) Data were recorded 45 days after sowing date.

b) Cabbage $10 \%$ as well as onion and garlic 5\% residues were decomposed in (EM1) or (EM5) 4 and $8 \%$.

c) Plants sprayed with water only and kept as a control treatment.

d) Plants sprayed with either EM1 or EM5 without decomposed plants. 
Table 7. Effect of foliar spraying 60 days after sowing date with some plant extracts decomposed in EM1 or EM5 as biotic formulas on faba bean (Giza 2) growth characters, pigments and chlorophyll content during two growing seasons

\begin{tabular}{|c|c|c|c|c|c|c|c|c|c|c|c|c|c|}
\hline \multirow[b]{3}{*}{ 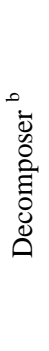 } & \multirow[b]{3}{*}{ 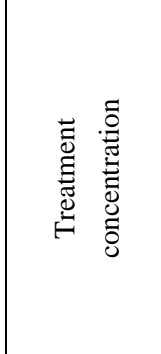 } & \multicolumn{6}{|c|}{ growing season $(2009 / 10)$} & \multicolumn{6}{|c|}{$2^{\text {nd }}$ growing season $(2010 / 11)$} \\
\hline & & \multicolumn{12}{|c|}{ Characters $^{\text {a }}$} \\
\hline & & 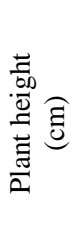 & 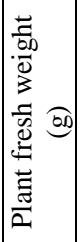 & 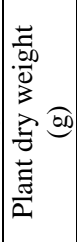 & 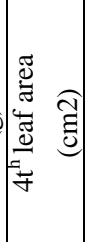 & 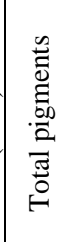 & 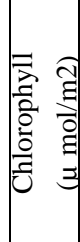 & 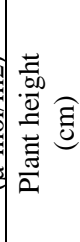 & 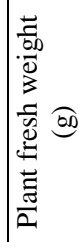 & 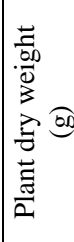 & 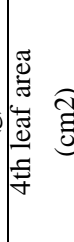 & 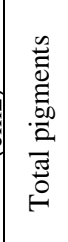 & 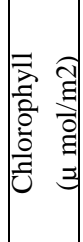 \\
\hline & Water $^{\mathrm{c}}$ & 55.7 & 34.2 & 4.6 & 4.32 & 37.3 & 407.4 & 43.6 & 30.3 & 4.0 & 3.53 & 34.7 & 464.3 \\
\hline \multirow{8}{*}{$\sum_{\text {II }}^{\overline{1}}$} & lone $4 \%^{\mathrm{d}}$ & 57.3 & 36 & 5.0 & 4.55 & 38.3 & 425.5 & 47.7 & 38.5 & 4.6 & 4.0 & 37.1 & 305.3 \\
\hline & Cabbage 4\% & 58.0 & 40.5 & 5.0 & 5.18 & 39.4 & 444.7 & 48.1 & 39.7 & 4.7 & 4.52 & 38.2 & 423. \\
\hline & Onion $4 \%$ & 59.0 & 43.3 & 5.2 & 5.33 & 41.0 & 474.6 & 48.7 & 43.2 & 4.7 & 4.55 & 38.3 & 436.8 \\
\hline & Garlic 4\% & 60.4 & 47.9 & 5.2 & 5.40 & 42.3 & 499.7 & 48.9 & 43.8 & 4.7 & 4.58 & 39.5 & 449 \\
\hline & Alone $8 \%^{\mathrm{d}}$ & 61.3 & 49.1 & 5.5 & 5.55 & 44.0 & 533.4 & 47.1 & 43.2 & 4.8 & 4.43 & 39.2 & 498 \\
\hline & Cabbage $8 \%$ & 61.9 & 50.5 & 5.5 & 5.60 & 44.8 & 550.1 & 50.9 & 48.0 & 5.1 & 4.85 & 42.1 & 520. \\
\hline & Onion $8 \%$ & 63.0 & 55.3 & 5.7 & 5.63 & 45.1 & 555.6 & 51.9 & 50.6 & 5.2 & 4.87 & 43.2 & 530. \\
\hline & Garlic $8 \%$ & 64.1 & 63.3 & 5.9 & 5.73 & 46.3 & 580.6 & 52.6 & 57.9 & 5.3 & 4.98 & 43.7 & 441 \\
\hline \multirow{8}{*}{$\sum_{i=1}^{n}$} & Alone $4 \%^{\mathrm{d}}$ & 67.2 & 77.7 & 7.8 & 5.97 & 47.2 & 600.1 & 56.3 & 73.2 & 5.6 & 5.15 & 45.7 & 563 \\
\hline & Cabbage $4 \%$ & 73.5 & 78.1 & 6.1 & 6.18 & 47.6 & 610 & 61.0 & 73.8 & 5.9 & 5.28 & 45.8 & 50 \\
\hline & Onion $4 \%$ & 75.3 & 79.7 & 6.4 & 6.23 & 48.4 & 628.2 & 61.7 & 74.2 & 6.3 & 5.40 & 46.2 & 57 \\
\hline & Garlic 4\% & 76.3 & 81.9 & 6.9 & 6.38 & 49.1 & 641.5 & 61.8 & 74.8 & 6.8 & 5.42 & 49.3 & 579 \\
\hline & Alone $8 \%^{\mathrm{d}}$ & 77.4 & 82.4 & 8.6 & 6.48 & 50.1 & 665.8 & 58.5 & 71.3 & 7.2 & 5.27 & 44.2 & 535.5 \\
\hline & Cabbage $8 \%$ & 79.2 & 85.0 & 8.8 & 6.68 & 51.2 & 690.5 & 64.6 & 79.5 & 8.4 & 5.83 & 48.9 & 63 \\
\hline & Onion $8 \%$ & 83.1 & 90.3 & 11.0 & 7.17 & 55.5 & 798.1 & 68.9 & 84.0 & 9.3 & 6.03 & 51.4 & 70 \\
\hline & Garlic & 81.8 & 88.3 & 9.3 & 6.78 & 51.7 & 703.2 & 68.2 & 82.0 & 9.0 & 5.97 & 50.5 & 67 \\
\hline \multicolumn{2}{|c|}{ LSD at 0.05} & 1.65 & 2.95 & 0.3 & 0.15 & 0.74 & 29.7 & 7.19 & 7.81 & 0.9 & 0.65 & 5.83 & 33.8 \\
\hline
\end{tabular}

$\left.{ }^{a}\right)$ Data were recorded 75 days after sowing date.

b) Cabbage $10 \%$ as well as onion and garlic 5\% residues were decomposed in (EM1) or (EM5) 4 and $8 \%$.

$\left.{ }^{c}\right)$ Plants sprayed with water only and kept as a control treatment.

d) Plants sprayed with either EM1 or EM5 without decomposed plants. 
Table 8. Effect of foliar spraying 30 or 60 days after sowing date with some plant extracts decomposed in EM1 or EM5 as biotic formulas on faba bean (Giza 2) yield and its attributes during two growing seasons

\begin{tabular}{|c|c|c|c|c|c|c|c|c|c|c|c|}
\hline \multirow{4}{*}{ 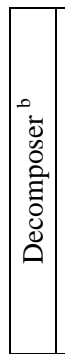 } & & & & & & & & & & & \\
\hline & \multirow[b]{3}{*}{ 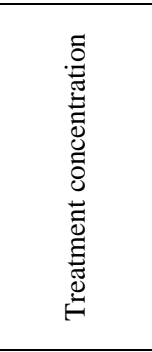 } & \multicolumn{5}{|c|}{$1^{\text {st }}$ growing season $(2009 / 10)$} & \multicolumn{5}{|c|}{$2^{\text {nd }}$ growing season $(2010 / 11)$} \\
\hline & & \multicolumn{10}{|c|}{ Character $^{\mathrm{a}}$} \\
\hline & & 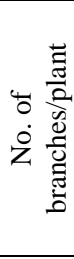 & 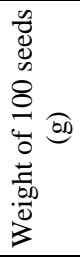 & 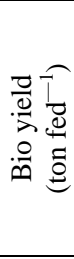 & 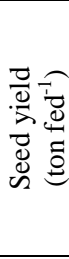 & 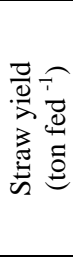 & 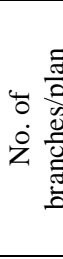 & 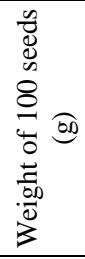 & 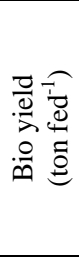 & 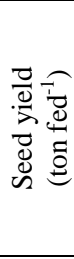 & 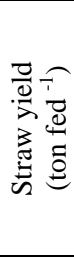 \\
\hline & Water $^{c}$ & 3.12 & 34.6 & 1.52 & 0.51 & 1.01 & 3.02 & 30.88 & 1.45 & 0.45 & 1.00 \\
\hline \multirow{8}{*}{$\sum_{I I}$} & Alone $4 \%{ }^{\mathrm{d}}$ & 3.15 & 34.2 & 2.18 & 0.82 & 1.36 & 2.87 & 32.64 & 2.0 & 0.78 & 1.22 \\
\hline & Cabbage $4 \%$ & 3.35 & 37.6 & 2.21 & 0.94 & 1.27 & 3.11 & 34.0 & 2.0 & 0.78 & 1.22 \\
\hline & Onion $4 \%$ & 3.33 & 40.2 & 2.26 & 0.95 & 1.31 & 3.15 & 37.14 & 2.0 & 0.82 & 1.18 \\
\hline & Garlic $4 \%$ & 3.53 & 42.0 & 2.34 & 0.98 & 1.36 & 3,27 & 39.63 & 2.22 & 0.98 & 1.24 \\
\hline & Alone $8 \%^{\mathrm{d}}$ & 3.32 & 43.5 & 2.52 & 1.00 & 1.52 & 3.14 & 38.64 & 2.25 & 1.1 & 1.15 \\
\hline & Cabbage $8 \%$ & 3.36 & 43.7 & 3.52 & 1.00 & 1.52 & 3.77 & 41.23 & 2.48 & 1.19 & 1.29 \\
\hline & Onion $8 \%$ & 4.20 & 45.7 & 2.92 & 1.17 & 1.75 & 3.91 & 41.48 & 2.68 & 0.95 & 1.73 \\
\hline & Garlic $8 \%$ & 4.25 & 47.4 & 2.95 & 1.19 & 1.76 & 2.98 & 43.87 & 2.70 & 0.96 & 1.74 \\
\hline \multirow{8}{*}{$\sum_{i=1}^{n}$} & Alone $4 \%^{\mathrm{d}}$ & 3.54 & 47.7 & 3.02 & 1.22 & 1.80 & 3.34 & 41.97 & 2.74 & 1.14 & 1.60 \\
\hline & Cabbage $4 \%$ & 3.96 & 47.8 & 3.12 & 1.24 & 1.88 & 3.49 & 43.71 & 2.95 & 1.16 & 1.79 \\
\hline & Onion $4 \%$ & 4.15 & 47.8 & 3.22 & 1.24 & 1.98 & 3.73 & 45.0 & 2.98 & 1.17 & 1.80 \\
\hline & Garlic $4 \%$ & 4.17 & 48.5 & 3.25 & 1.27 & 1.98 & 3.92 & 45.74 & 3.04 & 1.29 & 1,75 \\
\hline & Alone $8 \%{ }^{\mathrm{d}}$ & 4.17 & 45.3 & 3.15 & 1.24 & 1.91 & 3.95 & 41.98 & 2.83 & 1.18 & 1.65 \\
\hline & Cabbage $8 \%$ & 4.75 & 49.0 & 3.42 & 1.40 & 2.02 & 4.44 & 45.63 & 3.24 & 1.24 & 2.00 \\
\hline & Onion $8 \%$ & 5.03 & 51.8 & 3.66 & 1.46 & 2.20 & 4.57 & 48.83 & 3.39 & 1.39 & 2.00 \\
\hline & Garlic $8 \%$ & 4.86 & 51.7 & 3.58 & 1.40 & 2.18 & 4.53 & 46.6 & 3.25 & 1.31 & 1.94 \\
\hline \multicolumn{2}{|c|}{ LSD at 0.05} & 0.20 & 5.48 & 0.46 & 0.15 & 0.22 & 0.27 & 4.76 & 0.30 & 0.12 & 0.81 \\
\hline
\end{tabular}

${ }^{\text {a) }}$ Data were recorded at harvest time.

b) Cabbage $10 \%$ as well as onion and garlic 5\% residues were decomposed in (EM1) or (EM5) 4 and 8\%.

c) Plants sprayed with water only and kept as a control treatment.

d) Plants sprayed with either EM1 or EM5 without decomposed plants. 
Enzymes activity and total phenol content as affected by application with the nine recommended biotic formulas as inducers:

After the first season of the field experiment, only the first significant nine biotic formulas were selected to determinate the enzymes activity and total phenol content under greenhouse conditions. Results illustrated in Fig. (5) indicate that the foliar application of these biotic formulas as inducers increased gradually the enzymes peroxidase and polyphenoloxidase activity at 0,24 and 48 hours after inoculation with B. fabae, then decreased after 72 hours, compared to the control treatment. Concerning the total phenol content, results illustrated in Fig. (6) indicate that higher contents were obtained by foliar application with (EM5+garlic 8\%), (EM5+garlic $4 \%),($ EM5+onion $8 \%$ ) and (EM5+onion 4\%), respectively, compared to the control treatment.

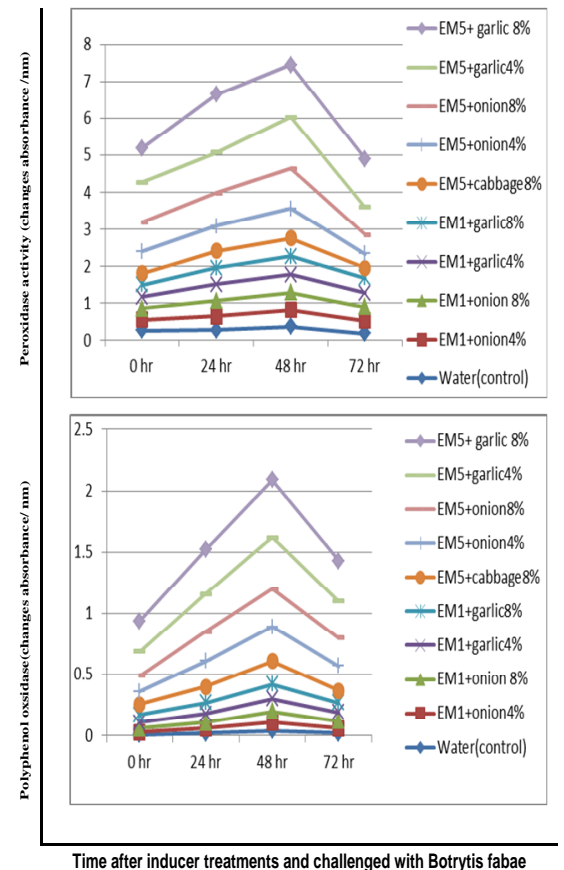

Fig. 5. Effect of foliar spraying with some plant extracts decomposed in EM1 or EM5 biotic formulas on enzymes activity of faba bean

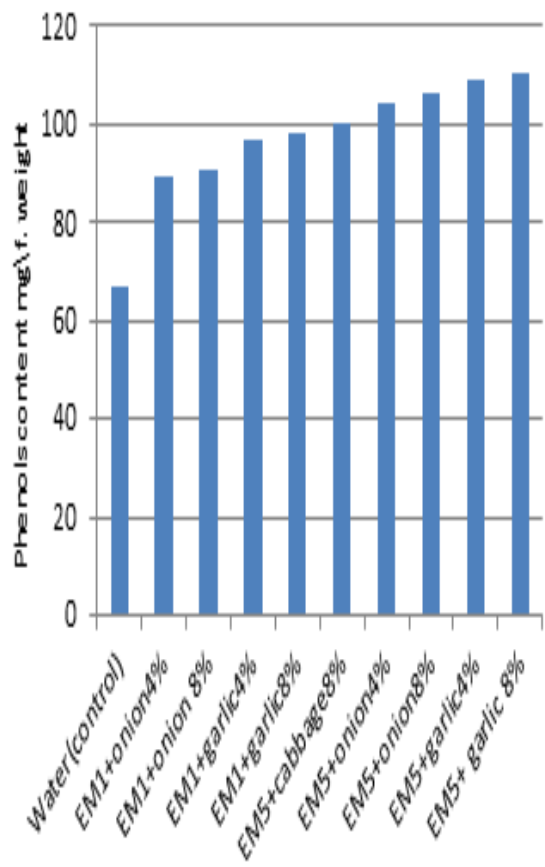

Fig.6. Effect of foliar spraying with some plant extracts decomposed in EM1 or EM5 as biotic formulas on total phenols content of faba bean

Egypt. J. Phytopathol., Vol. 42, No. 1 (2014) 


\section{D i s c us s i o n}

Garlic, onion and cabbage were recognized as rich in certain biochemicals that well known to induce plant resistance to several diseases (Karavina and Mandumba, 2012). Allium spp. (garlic and onion) show fungicidal effects referring to sulphur volatiles produced during degradation of allium tissues. (Auger et al., 2002 and Auger et al., 2004). The volatile antimicrobial substance allicin (diallylthiosulphinate) is produced in garlic and onion when the tissues are damaged and the substrate alliin (S-allyl-1-cysteine sulphoxide) mixes with the enzyme alliin-lyase (Lancaster and Collin, 1981 and Slusarenko et al., 2008). Sulphur compounds called Zuriebelanes $(\mathrm{Zw})$ are produced during degradation of onion residues (Block et al., 1992; Ferary and Auger, 1996 and Auger et al., 2004). Likewise, cabbage as one of the cruciferae plants is well known to have high content of sulphur compounds, oils gluycosides, glucosinolates as well as indoles. It also, produces biocidal compounds, principally isothiocyanets, which is produced during the decomposition of glucosinolates in cruciferae residues (Angus et al., 1994; Karavina and Mandumba, 2012; Hansen and Keinath, 2013 and Omirou et al., 2013). Therefore, these plants were selected to induce faba bean resistance to chocolate spot disease.

In order to naturally extract such biochemicals from the previously mentioned plants; an environmental procedure should be chosen. Thus, EM technology was selected, besides it provides an ecofriendly carrier for the proposed biotic formula aside from inducing some productivity improvement as a recovery from the disease infection. EM technology itself imbedded a wide variety of products. As EM1consists of lactic acid bacteria, yeasts, photosynthetic bacteria, actinomycetes and other types of organisms such as mycorrhizae which are mutually compatible with one another and coexist in based molasses liquid culture, while EM5 exceeds with ethyl alcohol and sugar cane vinegar (Higa, 1991 and Higa and Wididana, 1991a), so they seemed to be more applicable under the study conditions. Referring to EM1 \& EM5 biochemical structure; EM5 was superior to extract the biochemical materials from the decomposed plants as mentioned before for its continuity of bio-solvents such as ethyl alcohol and esters which naturally formed from vinegar and ethanol by the EM existed microorganisms. This can answer the query about the superior results obtained from EM5 application more than EM1 under both greenhouse and field conditions. Both EM1 and EM5 contained some alcoholic sugars such as manitol, which formed during the fermentation process from ethanol and glucose that already existed in the both bio-products (Higa, 2000).

As alcoholic sugars have a smaller liner shape molecule that was capable to enter the plant stomatal system easier and faster than any other molecule shape (Edwards et al., 1998), thus provides its physical features to the biochemicals when associated together. This could be interpreted both EM5 and EM1 eminent results, respectively, compared with water under both greenhouse and field conditions. Thus, the results obtained from the formulas that consisted when onion, garlic or cabbage were fermented in both EM1 and EM5 could be impliedly understood.

However, the integration that happened between the induced resistance and productivity on account of the biotic formulas application might need more 
clarification. Therefore, the second greenhouse experiment was carried out to prove the inducement of the disease resistance that drove to the productivity improvement as disease infection overcome. Consequently, only the nine significant promised biotic formulas, i.e. (EM1+onion 4\%), (EM1+onion 8\%), (EM1+garlic 4\%), (EM1+garlic 8\%), (EM5+cabbage 8\%), (EM5 + onion 4\%), (EM5+onion 8\%), (EM5+garlic 4\%) and (EM5+garlic 8\%), were selected for the total phenols content determination and enzymes activity evaluation. Obtained results completely agreed with those previously suggested by researches; as foliar application with different inducers increased in peroxidase and polyphenoloxidase activities compared to the control treatment. Peroxidase (PO) and polyphenoloxidase (PPO) activities are related to induce resistance in plants (Qin et al., 2003).

As a result of these enzymes activity, the oxidative power for the cross- linking of proteins and phenylpropanoid radicals was enhanced, resulting in reinforcement of cell walls against attempted fungal penetration (Kristensen et al., 1999). The increase in peroxidase activity enhanced lignifications in response to chocolate spot disease which may restrict fungal penetration (Tarrad et al., 1993). Peroxidase (PO) and polyphenoloxidase (PPO) activities are considered to be a preliminary indicator for resistance broad bean to chocolate spot disease. These findings indicate a positive relationship between resistance and enzymes activities (Orcutt and Nilson, 2000). In addition, peroxidase and polyphenoloxidase are activated by the inducers and the pathogen, resulting in the oxidation of phenolics to form quinones which are effective inhibitors of pathogens (Orcutt and Nilson, 2000). Different studies have shown that biochemical resistance through the accumulation of various phenolic compounds and phytoalexin and the activation of peroxidase, polyphenoloxidase and key enzymes in the phenylpropanoid and isoflavonoid pathways may play a crucial role in resistance to pathogen attack in plants.

The defence strategy of plants consists of two stages. The first stage is assumed to involve the rapid accumulation of phenols at the infection site, which function to slow the growth rate of the pathogens and to allow for the activation of a secondary stage that will more thoroughly restrict the pathogen. The secondary responses involve the activation of specific defence mechanisms such as the synthesis of molecules related to pathogen stress (Mohamed et al., 2007). Results of the present study also revealed the role of the inducers in the accumulation of phenols. As regards phenols, the higher accumulation of phenolic compounds in the treated plants challenged with the pathogen is an important criterion for considering the inducer for wider use. It is well known that synthesis of phenols occurs as an early response of plants to attempt infection by pathogens, as antimicrobial compounds, signal molecules, and cell wall strengthening components (Kruger et al., 2002).

Despite the bio formulas (EM5+garlic 8\%), (EM5+garlic 4\%), (EM5+onion 8\%) and (EM5+onion 4\%), respectively, were superior to induce plant resistance to faba bean chocolate spot disease, yet, the first one was correlated with plant leaves burned edges, that significantly decreased the total pigments and chlorophyll content, thus, decreased the photosynthetic capability, consequently plant growth and yield. Therefore, the other three bioformulas were recommended, respectively. While the resistance was induced as previously described, the two formulas of EM 
embedded some essential nutrients and phytohormones such as indols and cytokinins which improve the plant metabolism and productivity to give an appreciative recovery pathway (Higa, 2000) and this can explain the results obtained.

When taking into consideration the bioformulas time of application, it seemed that at 30 days after sowing date (vegetative growth stage) the plant was capable to recover the disease infection within the previously described pathways compared with at 60 days after sowing date (reproductive stage) as the infection significantly decreased the total chlorophyll content, thus photosynthetic capability accordingly the source-think relationships therefore, faba bean growth and yield.

\section{Con c l u s i o n}

In areas that experienced the chocolate spot disease infection caused by Botrytis fabae as a serious common biotic stress that significantly reduces faba bean growth and productivity, the foliar application of some biotic formulas as inducers is an obligation as a CDM concept in agriculture, in order to environmentally overcome the bad consequences of this disease. If the infection alert is existing at the vegetative stage; the foliar application either with (EM5+garlic) 4\%, (EM5+onion) $8 \%$ or (EM5+onion) $4 \%$ once at 30 days after sowing date is highly recommended. But if the alert postpones until the flowering or reproductive stage, foliar application with (EM5+garlic) $8 \%$ once at 60 days after sowing date is precisely a must.

\section{$R$ e f e r e n c e $s$}

Abou-Zeid, N.M. 1985. Contribution a L'amelioration de la resistance de Vicia faba L. au Botrytis fabae. These de Docteures Science University de Rennes, France.

Abou-Zeid, N.M. and Hassanein, A.M. 2000. Biological control of chocolate spot disease (Botrytis fabae Sard.) in faba bean in Egypt. J. Plant Pathol. Res. Inst., ARC, 90(6): 385-391.

Angus, J. F.; Gardner, P.A.; Kirkegaard, J. A. and Desmarchelier, J. M. 1994. Biofumigation isothiocyanates released from brassica roots inhibit growth of the take-all fungus. Plant and Soil, 162: 107-112.

Anonymous, 1976. Manual of Plant Growth Stage and Assessment Keys. Pinner: Ministry of Agriculture. Fisheries and Food (Publication).

Anonymous, 2011. Egyptian Agricultural Statistics. Part 1: The Winter Crops (2009-2010). Egyptian Central Agency for Public Mobilization and Statistics.

Auger, J.; Arnault, I.; Diwo-Allain, S.; Ravier, M.; Molia, F.; Pettiti, M.; Innophyt, C. and Cedex, O. 2004. Insectcidial and fungicidal potential of allium substances as biofumigants. Aroindustria, 3(3): 5-8.

Auger, J.; Dugravot, S.; Naudin, A.; Abo-Ghatra; Pierre, D. and Thibout, E. 2002. Possible use of allium allelochemicals in integrated control. IOBC WPRS Bull., 25: 295. 
Beye, F. 1978. Insecticides from the vegetable kingdom. PI. Res. Dev., 7: 13-31.

Block, E.; Putman. D. and Zhago, S. H. 1992. Allium chemistry GC-MS analyzed of thiosulfinates and rated compounds from onion, leek, scallion, shallot, chive and Chinese chive. J. Agric Food Chem., 40: 2431.

Chapman, H.D. and Pratt, P.F. 1978. Methods of analysis for soils plant and waters. Univ. California, Div. Agric. Sci. Priced Pub., 4034: 50 and 169.

Edwards, D; Kerp, H. and Hass, H. 1998. Stomata in early land plants: An anatomical and ecophysiological approach. J. Experim. Bot., 49: 255-278.

El-Hawa, M.A. 1998. Induction of fungal disease resistance in leguminosae. Egypt. J. Microbiol., 33(1); 147-154.

Epstein, S. S.; Andreae, M.; Jaffec, H.; Joshu, S.; Folk, H.; Natnel, N. and Yehia A.G. 1967. Carcinogenicity of the herbicide maleic hydrazide. Nature, 52(215): 1388-1390.

Fariduddin, Q.; Hayat, S. and Ahmed, A. 2003. Salicylic acid influences net photosynthetic rate, carboxylation efficiency, nitrate reductase activity and seed yield in Brassica juncea. Photosynthetica, 41(2): 281-284.

Ferary, S. and Auger, J. 1996. What is the true odor of cut allium? Complementary of various hyphenated methods gas chromatography-mass spectrometry and high-performance liquid chromatography-mass spectrometry with particle beam and atmospheric pressure ionization interfaces in sulphenic acids rearrangement component discrimination. J. Chromoatogr. A, 750: 63-74.

Hansen, Z.R. and Keinath, A.P. 2013. Increased pepper yields following incorporation biofumigation cover crops and the effects on soil-borne pathogen populations and pepper diseases. Appl. Soil Ecol., 63: 67-77.

Higa, T. 1991. Effective microorganisms: A biotechnology for mankind. Pages: 8-14. In Proc. $1^{\text {st }}$ Internat. Conf. on Kyusei Nature Farming. J.F. Parr; S.B. Hornick and C.E. Whitman (eds.). U.S. Dept. of Agric., Washington D.C., USA.

Higa, T. 2000. An agricultural revolution with EM technology. Page: 81. In: Our Future Reborn. Sunmark Pub. Inc., Japan.

Higa, T. and Wididana, G.N. 1991a. The concept and theories of Effective Microorganisms. Pages: 118-124. In: Proc. $1^{\text {st }}$ Internat. Conf. on Kyusei Nature Farming. J.F. Parr; S.B. Hornick and C.E. Whitman (eds.). U.S. Dept. of Agric., Washington D.C., USA.

Higa, T. and Wididana, G.N. 1991b. Changes in the soil microflora induced by effective microorganisms. Pages: 153-162. In: Proc. $1^{\text {st }}$ Internat. Conf. on Kyusei Nature Farming. J.F. Parr; S.B. Hornick and C.E. Whitman (eds.). U.S. Dept. of Agric., Washington D.C., USA.

Ismail, A.A. 2004. Phytotoxic effects of some growth inducers, fungicides, and a biocide on cotton seedlings under several conditions. Agric. Res. J. Tanta Univ., 30(1): 132-146. 
Javoraska, T. 1978. Effect of combined herbicides on the occurrence of morphoses in the spikes of spring barley. Agrochemia, 18: 37-42.

John, M.; Osterman, J.C and Mitchell, J. L. 1988. Calibration of the Minolta SPDA502 leaf chlorophyll meter. Photosynthesis Res., 48: 467-472.

Karavina, C. and Mandumba, R. 2012. Biofumigation for crop protection: Potential for adoption in Zimbabwe. J. Animal Plant Sci., 14: 1996-2005.

Kristensen, B.K.; Bloch, H. and Rasmussen, S.K. 1999. Barley coleoptile peroxidases. purification, molecular cloning and induction by pathogens. Plant Physiol., 120: 501-512.

Kruger, W. M.; Carver, T.W. and Zeyen, R.J. 2002. Phenolic inhibition of penetration resistance to Blumeria graminis f.sp. hordei in barley near isogenic lines containing seven independent resistance genes or alleles. Physiol. Mol. Plant Pathol., 61: 41-51.

Lancaster, J.E. and Collin, H.A. 1981. Presence of allinase in isolated vacuoles and of alkyl cysteines sulfoxides in the cytoplasm of bulbs of onion (Allium cepa). Plant Sci., 22: 169.

Latha, P.; Anand, T.; Ragupathi, N.; Prakasam, V.; Prakasam, V. and Samiyappau, R. 2009. Antimicrobial activity of plant extracts and induction of systemic resistance in tomato plants by mixtures of PGPR strains and zimmu leaf extract against (Alternaria solani). Biol. control, 50: 85-93.

Mansfield, J. W. and Deverall, B.J. 1974. The rate of fungal development and lesion formation in leaves of Vicia faba during infection by Botrytis cinerea and B. fabae. Appl. Biol., 76: 77-89.

Maxwell, D.P. and Bateman, F.D. 1967. Changes in the activities of some oxidases in extract of the Rhizoctonia-infected bean hypocotyls in relation to lesion maturation. Phytopathology, 57: 132.

Meenakshi, T. and Baldev, S. 2013. Role of elicitors in inducing resistance in plants against pathogen infection: A Review. ISRN Biochemistry, Vol. 2013, Article ID 762412 .

Mohamed, C.; Arbia, A.; Azza, R. 2007. Phenolic compounds and their role in biocontrol and resistance of chickpea to fungal pathogenic attacks. Tunis J. Plant Protect., 2(1): 7-21.

Obradovic, A. and Jones, J.B. 2005. Integration of biological control agents and systemic acquired resistance inducers against bacterial spot in tomato. Plant Dis., 89(7): 712-716.

Omirou, M.; Karpouzas, D.; Papadopoulou, K. and Ehaliotis, C. 2013. Dissipation of pure and broccoli- release glucosinolates in soil under high and low moisture content. Europ. J. Soil Biol., 60: 62-70.

Orcutt, D.M. and Nilson, E.T. 2000. Physiology of Plants Under Stress. John Wiley \& Sons, INC, New York, USA.

Egypt. J. Phytopathol., Vol. 42, No. 1 (2014) 
Qin, G.Z.; Tian, S. P.; Xu, Y. and Wan, Y.K. 2003. Enhancement of biocontrol efficacy of antagonistic yeasts by salicylic acid in sweet cherry fruit. Physiol. Mol. Plant Pathol., 62: 147-154.

Rewal, H. S. and Jhooty, J. S. 1985. Differential response of wheat varieties to systemic fungicides applied to Ustilago tritici Pers. Rostr. Indian J. Agric. Sci., 55: 548-549.

Ryals, J.S.U. and Ward, E. 1994. Systemic acquired resistance. Plant Physiol., 104: $1109-1112$.

Sahile, S.; Ahmed, S.; Fininsa, C.; Abang, M.M. and Sakhuja, P.K. 2008. Survey of chocolate spot (Botrytis fabae) disease of faba bean (Vicia faba L.) and assessment of factors influencing disease epidemics in northern Ethiopia. Crop Protect., 27: 1457-1463.

Singleton, V.L. and Rossi, J.A 1965. Colorimetry of total phenolics with phosphomolybdic-phosphotungstic acid reagent. Americ. J. Enol. Vitic., 16: $144-158$.

Slusarenko, A.J.; Patel, A. and Portz, D. 2008. Control of plant disease by nature products: Allicin from garlic as a case study. Europ. J. Plant Pathol., 121(3): 313-322.

Snedecor, G.W. and Cochran, W.G. 1980. Statistical Methods. $6^{\text {th }}$ Ed. Iowa State Univ. Press, Ames, Iowa, USA.

Sridhar, R. and Ou, S.H. 1974. Biochemical changes associated with development of resistant and susceptible types of rice blast lesion. Phytopathol. Z., 79: 222-230.

Steel, R.G.D. and Torrie, J.H. 1960. Principle and Procedures of Statistics. $2^{\text {nd }}$ Ed., McGrew-Hill, Kogakusha Ltd., NY, USA.

Sticher, L.; Mauch, M.B. and Metraux, J.P. 1997. Systemic acquired resistance. Annu. Rev. Phytopathol., 35: 235-270.

Strobel, N. and Kuc, J. 1995. Chemical and biological inducers of systemic resistance to pathogens protect cucumber and tobacco plants from damage caused by paraquat and cupric chloride. Phytopathology, 85(10): 1306-1310.

Tarrad, A.M.; El-Hyatemy, Y.Y. and Omar, S.A. 1993.Wyerone derivatives and activates of peroxidase and polyphenoloxidase in faba bean leaves as induced by chocolate spot disease. Plant Sci., 89(2): 161-165.

Torres, A.M.; Roman, B.; Avila, C.M.; Satovic, Z.; Rubiales, D.; Sillero, J.C.; Cubero, J.L. and Moreno, M.T. 2004. Faba bean breeding for resistance against biotic stresses: towards application of marker technology. Euphytica, 147: 67-80.

(Received 19/03/2014;

in revised form 20/04/2014) 


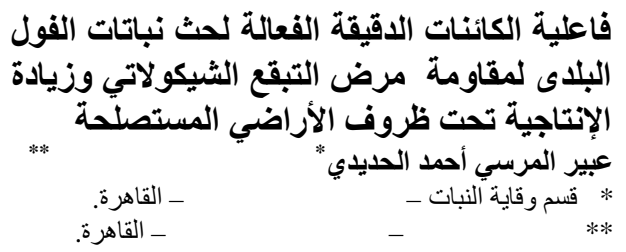

أجريت سلسلة من التجارب بالمعل والصوبة والحقل بمنطقة النوبارية التابعة لمحافظة البحبرة خلابل المبلة المواسم الثنتوبية

تأثير الرش ببعض المستحضر التهرات الحيوية التي تم تحضير ها بإستخدام

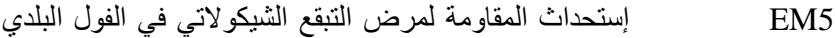

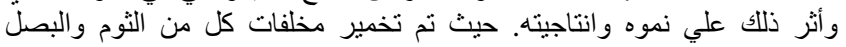
EM5 EM1

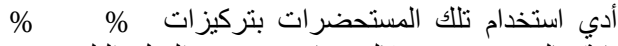

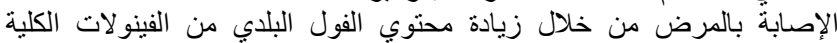

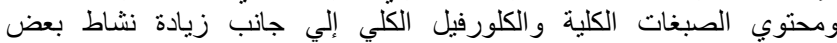
الإنزيمات. وقد ادي ذللك بالتبعية إلي زيادة نمو و إنتاجية الفول البلائ لإني.

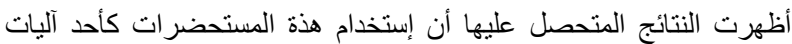

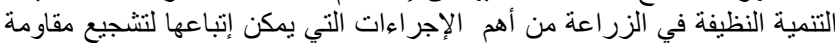

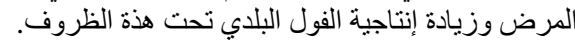

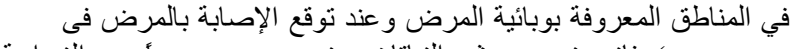

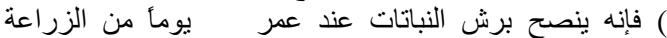

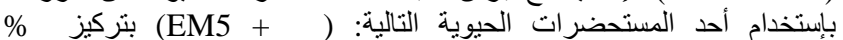

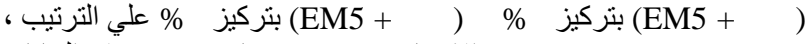
) فإنه ينصح برش النباتات (E)

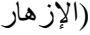

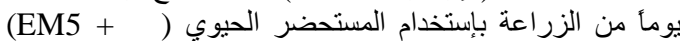

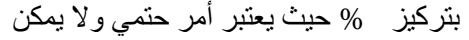

